\title{
DIETARY CONTRIBUTION OF UNDERUTILIZED MINOR FRUIT CROPS OF ASSAM IN NUTRITIONAL SECURITY-A REVIEW
}

\author{
SANCHAYEETA GOHAIN ${ }^{1} \&$ Dr. M. NEOG $^{2}$ \\ ${ }^{\text {I}}$ SMS, Krishi Vigyan Kendra, Tinsukia-786125, Assam, India \\ ${ }_{2}^{2}$ Professor, Assam Agricultural University, Jorhat-785013, Assam, India
}

\begin{abstract}
Underutilized fruits have an enormous possibility, to contribute to food and nutritional security, and livelihood improvement in a sustainable manner, but their role is often ignored or underestimated. Assam is blessed with more than twenty varieties of minor fruits and they are a rich source of minerals, fat, protein, carbohydrate and dietary fibre etc. Thus, they not only have the nutritional ability to avert and cure various nutritional deficiency related diseases but also to combat hunger. So, the consumption of these underutilised fruits which are seasonal, easily available and cheaper can help to overcome the rural population's nutritional deficiency. The underutilized fruits are not only climate resilient in nature but also resistant to biotic and a biotic stress conditions. The underutilized minor fruits can lessen the burden on the major fruits if cultivated commercially.

KEYWORDS: Underutilized, Minor Fruits, Dietary Contribution, Nutritional Security, Income
\end{abstract}

Received: Jun 19, 2020; Accepted: Jul 10, 2020; Published: Aug 07, 2020; Paper Id.: IJASRAUG202019

\section{INTRODUCTION}

Assam is considered as a biodiversity hotspot, with many minor fruits which are rich source of proteins, vitamins, minerals, fat, fibre etc. But the potential of these underutilized fruits to contribute to dietary nutrition as well as to improve the quality of livelihood are not fully explored. The minor fruits of Assam can play ahumongous role in decreasing the food and nutritional insecurity and improving income generation of the rural masses in particular. The advantages of the underutilized fruits are many fold. They are climate resilient in nature and have medicinal value. But despite having these advantages, the underutilized minor fruits plants are not cultivated commercially and hence their availability in the market is also rare. The attention these plants receive from research or policy makers are also limited.

\section{THE POTENTIAL OF UNDERUTILIZED FRUITS IN NUTRITIONAL SECURITY}

Underutilized fruits are highly beneficial and valuable. These underutilized plants can help to make diets more balanced by enhancing nutritional quality of the food. In rural areas of India including Assam, there is high prevalence of malnutrition and also being underweight, especially among children and women. These problems can be tackled by consumption of underutilized fruits and vegetables which are known sources of minerals portions and vitamins. The most concentrated form of vitamin C $(500-600 \mathrm{mf} / \mathrm{g})$ is found, along with high antioxidant properties, in Amla which isa known minor fruit of India. Fig is another important fruit used from ancient time, which is very rich in proteins and carbohydrates. Another wildly available fruit of Assam, which is popular among locals due to its exclusive flavour and aroma is Passion fruit, which is a great source of ascorbic acid, vitamin A, high mineral 
content, niacin and riboflavin. Jujube is also underutilized fruit which has the ability to enrich the food by providing essentials minerals including potassium, phosphorous, manganese and also iron, zinc and copper. Jujube can provide 79 Kcal per $100 \mathrm{gm}$ of fruit. Beralso comes under the underutilized fruit category but is packed with carotene, calcium, protein, phosphorus, and Vitamin $\mathrm{C}$, which is higher than many major fruits like apple. To eradicate the problem of malnutrition and hunger from the world, it is necessary to concentrate on production of indigenous and underutilized fruits so that the deficiency in nutrition intake in food can be minimised by adding these minor fruits into the diet.

\section{UNDERUTILIZED FRUIT SPP AS SOURCES OF PROTEIN}

The required amount of protein for male is $60 \mathrm{gm}$ and $50 \mathrm{gm}$ for female in diet day as part of 2000 calorie diet as they are one of the building blocks of body tissue. . Many underutilized fruits of Assam are rich in protein which can contribute a lot to the dietary supplement of poor people. Following are the list of the protein content of some underutilized fruits found in Assam (Table1).

Table 1: Protein Content of Some Underutilized Fruits of Assam

\begin{tabular}{|c|c|c|}
\hline Local Name & Scientific Name & Protein Content $(\mathrm{gm}) / \mathbf{1 0 0}$ gm \\
\hline Jamun & Sizium cumminii & 0.70 \\
\hline Jack fruit & Artocarpus heterophyllus L. & 1.74 \\
\hline Carambola & Averrhoa carambola Linn & 0.85 \\
\hline D. Indica & Dillenia indica Linn & 2.30 \\
\hline Tengamora & Hibiscus sabdarifa & 7.51 \\
\hline Atlus & Annona squamosal (Linn.)Alston & 5.2 \\
\hline Nuni & Morus alba L. & $0.5-1.4$ \\
\hline Kujithekera & Garcinia cowa Roxb. & 2.43 \\
\hline Borthekera & Garcinia pedunculata Roxb. & 4.65 \\
\hline Leteku & Baccaurea ramiflora Lour & 5.58 \\
\hline Beal & Angelo armelos, correa & 1.6 \\
\hline Naga tenga & Rhus semialata Murr. & 1.36 \\
\hline
\end{tabular}

Source: Annon (2002), Gopalan et al. (1978), Gogoi(2007), Firdusi, (2008), Singhal et al., (2009), Kokate, 2014, Singh et al. (2014)

\section{UNDERUTILIZED FRUIT SPP AND FAT}

Fat is one of the essential constituent of diet. Fat provide more than half of the body's energy needs, absorbs certain nutrient (Vitamin A, D, E and $\mathrm{K}$ require fat to function), and maintains the core body temperature and hence can be considered as vital. The fat intake should be $15-25 \mathrm{~g} /$ day in terms of oil content of fruits and other food products. For people below poverty line, deficiency of fat in the diet is a major concern which can be mitigated by adding traditionally available underutilized minor fruits. Following underutilized fruits are rich sources of fat. (Table 2). 
Table 2: Fat Content of Some Underutilized Fruits of Assam

\begin{tabular}{|l|l|c|}
\hline \multicolumn{1}{|c|}{ Local Name } & \multicolumn{1}{|c|}{ Scientific Name } & Fat Content (gm)/100 gm \\
\hline Jamun & Sizium cumminii & 0.70 \\
\hline Jack fruit & Artocarpus heterophyllus L. & 0.64 \\
\hline Carambola & Averrhoa carambola Linn & 0.85 \\
\hline D. Indica & Dillenia indica Linn & 2.30 \\
\hline Tengamora & Hibiscus sabdarifa & 7.51 \\
\hline Atlus & Annona squamosal (Linn.)Alston & .48 \\
\hline Nuni & Morus alba L. & 2.43 \\
\hline Kujithekera & Garcinia cowa Roxb. & 4.65 \\
\hline Borthekera & Garcinia pedunculata Roxb. & - \\
\hline Leteku & Baccaurea ramiflora Lour & 0.2 \\
\hline Beal & Angelo armelos, correa & 1.36 \\
\hline Naga tenga & Rhus semialata Murr. & $\mathrm{m}$ \\
\hline
\end{tabular}

Source: Annon (2002), Gopalan et al. (1989), Gogoi(2007), Firdusi, (2008), Singhal et al., (2009), Kokate, 2014, Singh et al (2014)

\section{UNDERUTILIZED FRUIT SPP AND CARBOHYDRATES}

The human body requires carbohydrates to function properly as along with fat and protein it one of major macro nutrients that provide energy. The per day intake of carbohydrates should be 225-325 gm which can be addressed by consumption of minor fruits.

Following underutilized fruits are rich source of carbohydrate. (Table 3).

Table 3: Carbohydrate Content of Some Underutilized Fruits of Assam

\begin{tabular}{|l|l|c|}
\hline \multicolumn{1}{|c|}{ Local Name } & \multicolumn{1}{|c|}{ Scientific Name } & Carbohydrate Content (gm)/100 gm \\
\hline Jamun & Sizium cumminii & 97.59 \\
\hline Jack fruit & Artocarpus heterophyllus L. & 23.5 \\
\hline Carambola & Averrhoa carambola Linn & 9.38 \\
\hline D. Indica & Dillenia indica Linn & 9.05 \\
\hline Tengamora & Hibiscus sabdarifa & 69.62 \\
\hline Atlus & Annona squamosal (Linn.)Alston & 59 \\
\hline Nuni & Morus alba L. & $7.8-9.0$ \\
\hline Kujithekera & Garcinia cowa Roxb. & 55.84 \\
\hline Borthekera & Garcinia pedunculata Roxb. & 56.85 \\
\hline Leteku & Baccaurea ramiflora Lour & 51.9 \\
\hline Beal & Angelo armelos, correa & 31.80 \\
\hline Naga tenga & Rhus semialata Murr. & 21.89 \\
\hline
\end{tabular}

Source: Annon (2002), Gopalan et al. (1989), Gogoi(2007), Firdusi, (2008), Singhal et al., 2009, Kokate, 2014,

Singh et al (2014)

\section{UNDERUTILIZED FRUIT SPP AND FIBRE}

Dietary fibre is significant in a healthy diet as it can provide many benefits to the body. Fibre helps to maintain the bowel health, lowers the cholesterol levels, helps control the blood sugar level and maintain weight. Various underutilized fruits of Assam can fulfil the dietary requirement of fibre per meal (Table 4). 
Table 4: Fibre Content of Some Underutilized Fruits of Assam

\begin{tabular}{|c|c|c|}
\hline Local Name & Scientific name & Fibre Content $(\mathrm{gm}) / 100 \mathrm{gm}$ \\
\hline Jamun & Sizium cumminii & 0.90 \\
\hline Jack fruit & Artocarpus heterophyllus L. & 1.5 \\
\hline Carambola & Averrhoa carambola Linn & 0.90 \\
\hline D. Indica & Dillenia indica Linn & 1.60 \\
\hline Tengamora & Hibiscus sabdarifa & 11.10 \\
\hline Atlus & Annona squamosal (Linn.)Alston & 11 \\
\hline Nuni & Morus alba L. & $0.9-1.3$ \\
\hline Kujithekera & Garcinia cowa Roxb. & 10.34 \\
\hline Borthekera & Garcinia pedunculata Roxb. & 9.57 \\
\hline Leteku & Baccaurea ramiflora Lour & 20.4 \\
\hline Beal & Angelo armelos, correa & 2.90 \\
\hline Naga tenga & Rhus semialata Murr. & 3.51 \\
\hline
\end{tabular}

Source: Annon (2002), Gopalan et al. (1989), Gogoi(2007), Firdusi, (2008), Singhal et al., 2009, Kokate, 2014,

Singh et al, (2014)

\section{UNDERUTILIZED FRUIT SPP AND MINERALS}

Minerals supplement is a must in diet as it is required to perform various functions in a body. Calcium is required for healthy bones, phosphorous is needed to maintain the acid-base balance, Sodium for nerve transmission and magnesium is needed by the immune system. Underutilized fruits are considered to be a reservoir of various mineral nutrients. (Table 5).

Table 5: Mineral Content of Some Underutilized Fruits of Assam

\begin{tabular}{|l|l|c|}
\hline \multicolumn{1}{|c|}{ Local Name } & \multicolumn{1}{|c|}{ Scientific Name } & Mineral Content (gm)/100gm \\
\hline Jamun & Sizium cumminii & 0.40 \\
\hline Jack fruit & Artocarpus heterophyllus L. & 0.90 \\
\hline Carambola & Averrhoa carambola Linn & 0.40 \\
\hline D. Indica & Dillenia indica Linn & 3.54 \\
\hline Tengamora & Hibiscus sabdarifa & 11.24 \\
\hline Kujithekera & Garcinia cowa Roxb. & 1.75 \\
\hline Borthekera & Garcinia pedunculata Roxb. & 1.63 \\
\hline Beal & Angelo armelos, correa & 1.9 \\
\hline Naga tenga & Rhus semialata Murr. & 0.387 \\
\hline
\end{tabular}

Source: Annon (2002), Gopalan et al. (1989), Gogoi(2007), Firdusi, (2008), Singhal et al., (2009), Kokate, 2014, Singh et al (2014)

\section{CONCLUSIONS}

The most significant fact about the underutilized fruit spp is that they are capable of taking the on challenge of malnutrition and hunger to a great extent especially in economically poor countries. These crops can be grown in a wide range of climactic and soil conditions and are cost effective. Underutilized crop species, if explored properly, can not only help in improving the livelihood of poor people but also intensify the horticultural production of a nation. India has about $150 \mathrm{spp}$ of consumable underutilized fruits but their commercial cultivation has not yet been promoted. Sustainable exploration of the minor underutilized fruits will also lessen the burden of over dependency on the major fruit crops. So there is an urgent need to focus on the benefits of minor neglected fruits of the region from the researchers, policy makers and extension personnel. 


\section{REFERENCES}

1. Annon, 2002. Final report of Ad-hoc Scheme on preservation and processing of some important indigenous fruits of Northeast India with especial reference to Assam (1999-2002). Assam Agricultural University

2. Craig W. and Beck L. 1999. Phytochemicals: health protective effects. Canadian Journal ofDietaryPractice60:78-84

3. Chandrarathne R. 2007. Under-utilized crops and fight against hunger and poverty. Sunday Observer, 6th May 2007. DOI: http://dx.doi.org/10.1057/9781137491213.0008

4. Firdusi N S. 2008. Physico -biochemical characterization and value addition to selected minor fruits of Assam. PhD Thesis, Assam Agricultural University.

5. Brahimi, Latifa, and Zahr-Eddine Djazouli. "Diet Stress Effect on Adaptive Strategy of Black Buprestidae Capnodis Tenebrionis (Coleopteran: Bupresdae) Translated by its Energy-Giving Allotments Fluctuations." International Journal of Agricultural Science and Research (IJASR) 4.3 (2014): 79-89.

6. Gopalan C, Ramashastri B V, BalasubramanianS C, RaoNB S, DeosthaleY G. and Pant K C.1989. Nutritive value of Indian Foods, ICMR Hyderabad: National Institute of Nutrition.

7. Gopalan C. 1992. Variations in food consumption patterns of population. Nutrition Foundation of Indian Bulletin. 13(4): 5-6

8. Gopalan C, Ramashastri B V, BalasubramanianS C, RaoNB S, DeosthaleY G. and Pant K C.1994. Nutritive Value of Indian Foods, National Institute of Nutrition, ICMR Hyderabad.

9. Idouhar-Saadi, H. A. B. I. B. A., et al. "Diet comparison between fledgling and adult tawny owl StrixalucoLinné, 1758 (Aves; Strigidae) in suburban area of El Harrach (Algiers, Algeria)." International Journal of Zoology and Research 4.4 (2014): 59 66.

10. Gogoi A K. 2007. Minimal processing for short term preservation of jackfruit bulbs. Master'sThesis, Assam Agricultural University.

11. Hoeschle-ZeledonI. and Bordoni, P. 2003. Approaches and decision steps for the promotion and development of underutilized plant species. Global facilitation unit for Underutilized species. Rome, Italy. DOI: http://dx.doi.org/10.1079/9781845930998.0605

12. Hoeschle I, Zeledon, and Jaenicke H. 2009. A strategic framework for research and development of underutilized plant species with special reference to Asia, the pacific and sub Saharan Africa. DOI: http://dx.doi.org/10.17660/actahortic.2009.818.49

13. Kokate S. 2014. Amazing healing power of custard apple. Conference paper

14. Ahlem, L. A. I. S. S. O. U. F., et al. "Dietary Flaxseed Oil supplementation improves the oxidant/antioxidant status in obese aged rats." IJMPS 3.2 (2013): 87-94.

15. Kader AA, Veazi P P, and Lester G E. 2005.Nutritional Quality of Fruits, Nuts, and Vegetables and Their Importance in Human Health, Department of Pomology, University of California, Davis, CA.

16. Kunkel G. 1984. Plants for human consumption. Koeltz Scientific Books, Koenigstein, Germany Malkanthi S H P, Karunaratne A S, Amuwala S D, and Silva P. 2014. Opportunitiesand Challenges in Cultivating Underutilized Field Crops in Moneragala District of Sri Lanka. Asian Journal of Agriculture and rural Development, 4(1): 96-105.

17. Neog M, and Mohan NK. 1996. Minor and less known fruits of Assam. Indian Horticulture.39: 28-31 
18. Alhajri, Amenah, Rima Mashal, and Salma Tukan. "Studying The Effect of Dietary Advanced Glycation End Products on Type II Diabetes and Related Complications Risk."International Journal of Applied and Natural Sciences (IJANS) 7. 4, Jun - Jul 2018; 55-66

19. Quebedeaux B and Eisa H M. 1990. Horticulture and human health. Contributions of fruits and vegetables. Horticulture and Human Health. Horticulture Science, 25: 1473-1532. Proc. 2nd Intl. Symp.

20. Reddy V. 1991. "Protein-energy malnutrition". In Diseases of children in the subtropics and tropics, edited by StanfielP., Brueton M., ChanM., Parkin M. and Waterson, T. Edward Arnold.

21. Singhal B K, Dhar A, Khan M A, Sengupta D, and Dhar S L. 2009 . Mulberry by-products utilization for sustenance of sericulture industry of Jammu and Kashmir. Proc. The 20th Congress of the International Sericultural Commission, Vol. I, Central Silk Board, Bangalore, pp. 152-156.

22. Singh A, Sharma H K, Kaushal P, and Upadhay A. 2014. Bael (Angeloarmelos, correa) products processing: A review : African Journal of Food Science ,8(5):204-215.

23. Swaminathan M S. 1999 . Food Security and agro-biodiversity, valuing the global environment, action and investment for 21 st century. Global Environment Facility, Swift, S.D. (Ed.). Washington, DC. pp: 54-55.

24. Taylor M, Jaenick H, Skelton P, and Mathur P N. 2009. Regional Consultation on Crops for the Future: Towards Food, Nutritional, Economic and Environmental Security in the Pacific, National Agricultural Research Institute. DOI: http://dx.doi.org/10.17660/actahortic. 2011.918 .49

25. Williams J T, and Haq N. 2010 .Underutilized Crops for Food Security and Poverty Alleviation, ICUC. University of Southampton, Southampton SO17 1BJ, UK. DOI: http://dx.doi. org/10.1895/wormbook.1.143.2 